\title{
Research and Practice of Construction of Automobile Detection and Maintenance Teaching Team
}

\author{
Peijiang Chen \\ School of Automobile, Linyi University \\ Linyi, Shandong, China \\ chenpeijiang@163.com
}

\begin{abstract}
In order to improve the teaching quality, it is essential to strengthen the construction of teaching team which is an important project of teaching quality engineering. Making the teaching team of automobile detection and maintenance of Linyi University as an example, the construction of teaching team is studied and practiced. On the basis of analyzing the current status of the teaching team, the construction goal of teaching team is proposed. The construction programs is put forward from the teaching staff, teaching research and teaching reform, scientific research and other aspects. From the implementation effect, the construction of teaching team has gotten certain achievements in student training, specialty development, teaching reform, and it has certain features and influence.
\end{abstract}

Keywords-automobile detection and maintenance; teaching team; building programs; quality engineering

\section{INTRODUCTION}

In colleges and universities, improving the teaching quality is an important guarantee and necessary prerequisite to train high-quality students [1-3]. Teaching team construction is an important part of the teaching quality project and it is one of the key aspects of teaching reform [4-6]. Teaching team construction focuses on a teaching staff with high teaching quality and rational structure, effective teamwork mechanism, teaching discussion and teaching experience exchange, teaching resources development, combing of old, middle-aged and young teachers, young teachers training [7-8].

The teaching team of automobile detection and maintenance in Automobile School of Linyi University is a school-level outstanding teaching team, and it is mainly responsible for teaching of automobile-majored courses. In order to improve the teaching team of automobile detection and maintenance, on the basis of analyzing the current situation of teaching team, the construction goal and construction program are put forward.

\section{CONSTRUCTION STATUS OF AUTOMOBILE DETECTION AND MAINTENANCE TEACHING TEAM}

The Adult Higher Education Teaching Reform and Development Policy Research Project of Shandong, China, the Teaching Reform Project of Linyi University(No. 2014016), and the Teaching Quality Engineering Project of Linyi University in 2014.
The teaching team of automobile detection and maintenance in Linyi University has 11 teachers, including 10 full-time teachers. There are 3 doctors and 7 masters, 4 professors and 4 associate professors, including 2 academic leaders, 3 middle-aged backbone teachers. It is one of the key teaching teams of automobile school.

The teaching team is mainly responsible for the specialized courses teaching of automobile majors, including vehicle engineering undergraduate, automobile service engineering undergraduate, automobile application technology specialist, the main courses, class hours and teachers are given, as shown in Table 1.

TABLE I. THE MAIN COURSES, HOURS AND TEACHERS OF THE AUTOMOBILE DETECTION AND MAINTENANCE TEACHING TEAM

\begin{tabular}{|c|c|c|}
\hline Course & Hours & Teachers \\
\hline Automobile Structure & 64 & $\begin{array}{l}\text { Guangwei Han, } \\
\text { Wenyong Li }\end{array}$ \\
\hline Engine Principle & 48 & Xiao Mi, Jonel \\
\hline $\begin{array}{c}\text { Automobile Electronic and } \\
\text { Electrical Equipment }\end{array}$ & 48 & $\begin{array}{c}\text { Xuehua Jiang, } \\
\text { Xiao Mi } \\
\end{array}$ \\
\hline Engineering Testing Technology & 48 & $\begin{array}{l}\text { Peijiang Chen, } \\
\text { Lin Zhao }\end{array}$ \\
\hline $\begin{array}{c}\text { Automobile Detection } \\
\text { Technology }\end{array}$ & 48 & Jonel, Peijiang Chen \\
\hline $\begin{array}{l}\text { Automobile Maintenance } \\
\text { Technology }\end{array}$ & 48 & $\begin{array}{l}\text { Hongzhong Li, } \\
\text { Lin Zhao }\end{array}$ \\
\hline Automobile Testing Theory & 48 & $\begin{array}{l}\text { Bing Zhong, } \\
\text { Guangwei Han }\end{array}$ \\
\hline $\begin{array}{c}\text { Automobile Assembly and } \\
\text { Disassembly Training }\end{array}$ & 1 week & Guangwei Han, Jonel \\
\hline $\begin{array}{c}\text { Automobile Maintenance } \\
\text { Training }\end{array}$ & 1 week & Wenyong Li, Jonel \\
\hline
\end{tabular}

After years of construction, the overall quality of the teaching team is steadily improving, the ranks of teachers are continuously growing, the knowledge structure and age structure of full-time teachers are more reasonable, the proportion of double capability teachers increases continuously, and the teaching level enhance unceasingly. 


\section{CONSTRUCTION GOAL OF AUTOMOBILE DETECTION AND MAINTENANCE TEACHING TEAM}

Based on the discipline and specialty construction of vehicle engineering and automobile service engineering, focusing on specialized courses, the automobile detection and maintenance teaching team is built to form a reasonable mechanism, implement and promote the teaching reform and curriculum construction, achieve good teaching effect, stimulate the young teachers' enthusiasm, improve teachers' cohesion and solidarity, construct a teaching team with certain characteristics, and provide service for vehicle engineering and other automobile specialties.

\section{A. Strengthen the training of team leaders and key teachers, promote team development}

In order to train team leader, the principle of "emphasis on on training, selecting new qualified" is persevered. Supporting team leader to participate in teaching research and academic seminars, take part in retraining and business practices at home and abroad, which can enhance the theoretical level, teaching ability and specialized technical level. Implementing staff training and comprehensive continuing education, encouraging teachers for their further study for doctorate degree and training young teachers, this can form the backbone teachers and promote the healthy and orderly development of teaching team.

\section{B. Construct related disciplines, cultivate high-quality talents}

The teaching team has two second-rate related disciplines: vehicle engineering and automotive service engineering. Taking the regional economic development, industrial planning and enterprise demand as orientation, the team turns to training high-quality applied engineering and technical personnel who have the basic knowledge and practical abilities of automobile detection and maintenance, and can influence and lead the similar related disciplines, including mechanical engineering, electrical engineering and control engineering, etc.

\section{Focusing on course construction, strength course reform}

It should give full play to the leading role of the team in teaching reform and strengthen the construction of excellent courses. The teaching methods, heuristic, discussion and research should be strongly recommended, the practical teaching should be promoted. A stable technological innovation teacher team should be formed to guide students to participate in scientific research and social practices and promote the overall quality of students.

\section{Strengthen scientific research, improve academy standard}

The teachers are encouraged to strengthen the scientific research, apply various research projects actively at all levels and form relatively stable research direction and fixed technical team. Aiming at the key scientific problem of the current regional automobile industry production, it should be further studied. At the same time, the research should be closely linked with actual production to improve the conversion rate of scientific and technological achievements and promote the development regional economy.

\section{E. Complete basic conditions construction, create good team environment}

In order to deepen the scientific research and teaching, it should increase investment and further improve the basic conditions of teaching and research. The automobile engineering training center must be built unceasingly, the related equipment are purchased to improve the basic experimental conditions. A technology platform should be built for the team to lay the technical foundation of the in-depth research.

\section{CONSTRUCTION PROGRAMS OF AUTOMOBILE DETECTION AND MAINTENANCE TEACHING TEAM}

According to the construction goal of automobile detection and maintenance teaching team, the construction programs is made.

\section{A. Teaching staff construction}

In order to improve the overall quality of teachers as the core, it is necessary to build a teaching team in sufficient numbers, reasonable echelon and comprehensive quality.

(1) Based on the development needs of teaching team, recruiting talented teachers can further improve the professional source structure of the team.

(2) Intensify the efforts to enhance the teaching ability of young teachers. It is an important task for teaching team to train young teachers, which can improve the academic qualifications and titles of the existing teachers

(3) The team invites experts and scholars to carry out professional lectures annually, and encourages teachers to go out and participate in refresher training and business practices at home and abroad.

(4) It is important to actively strengthen cooperation with other universities and companies and hire engineers with rich practical experience to assume the task of teaching training courses.

(5) The professional structure and construction thoughts of teaching team should be adjusted and improved constantly. The teaching team building seminars or experience exchange must be hold at least once each semester.

\section{B. Teaching research and teaching reform}

The teaching team focuses on improving the teaching quality and training qualified personnel. Taking quality education as the guiding ideology, the teaching reform is promoted actively. Based on professional construction and development, the course construction and teaching reform is strengthened.

(1) Linyi Xindayang, Yuantong Automobile Group, and other units are discussed with the personnel training programs. The ideas of talents cultivation are penetrated into training objective and courses.

(2) The reform of teaching methods should be carried out to promote the experiment of project-oriented, task-driven and other teaching modes. 
(3) The multimedia courseware should be further improved to enhance the teaching quality.

(4) The Automobile Engineering Training Center must be constructed further. Reforming the training course content, the teaching team trains the innovative awareness, innovation ability and enterprising sprit of students.

(5) It is important to establish new practice bases outside the school to form excellent training environment.

(6) The research of teaching projects should be actively carried out, declaring teaching reform projects and constructing excellent courses.

(7) In the teaching process, the superior teaching material of Ministry of Education must be preferred. At the same time, the teachers should compile teaching material based on the course content and the information of teaching and learning.

(8) Based on the network teaching platform, the online courses are built to broaden students' learning channels.

\section{Strengthen research capacity, promote teaching}

(1) The teaching team should further sharpen research orientation and focus. The team leader should have a relatively stable research direction; closely follow the trend of international academic development, and constantly cultivating new growth points and opening up new research areas.

(2) The scientific research should closely contact with actual production, improve the conversion rate of scientific and technological achievements and promote the regional economic development.

(3) It should strengthen innovative scientific research, actively apply various research projects at all levels and publish high levels of academic papers.

(4) The scientific achievements should be turned into teaching by course notes, lectures, and other means.

\section{FEATURES OF OF AUTOMOBILE DETECTION AND MAINTENANCE TEACHING TEAM}

The teaching team of automobile detection and maintenance gives great importance to the construction of teaching faculty, actively carries out teaching reform and innovation, increases experimental practice teaching efforts, builds and improves the teaching resources and networks teaching. Based on the several years' teaching reform, the team enriches and enhances in every respect constantly, and the own characteristics have been formed initially.

\section{A. Features of team setting}

The teaching team has reasonable academic structure, professional knowledge structure, age structure and title structure. The teachers have a strong sense of responsibility and good teamwork spirit. The team focus on reform and innovation of theory and experiment teaching, and the teaching effect is remarkable and the teaching quality is excellent. The teaching team has strong research awareness, can actively track the academic front. The teachers can be able to combine the teaching and research, and actively promote the relevant professional teaching and reform.

\section{B. Feasible and innovative reform measures}

The teaching team establishes advanced teaching philosophy, focuses on teaching reform, actively promotes the task-based and project-based teaching model [9-10]. The trinity education mode of knowledge, ability and quality are implemented effectively, which can strengthen students' innovative spirit and practical ability.

In personnel training, focusing on the employment orientation of automobile maintenance and detection industry, it updates the orientation of talent training, emphasizes on training high-quality application-oriented talents with strong practical ability and capable of innovation.

In course construction, based on the typical work task of automobile maintenance and testing, according to the required knowledge of the working process, the teachers determine the teaching content and objectives design the basic teaching modules and innovate the curriculum system and teaching content.

In teaching mode, based on the real task, the teaching team designs the learning situations and learning tasks, and develops educational programs based on the task. In practice, the atmosphere of automobile industry is created by using professional training workshop and training facilities to develop students' practical operation skills.

In teaching methods, aiming at the contents characteristics and requirements of different courses, a variety of teaching modes are adopted to enhance the intuitive of teaching, fully mobilize the enthusiasm of students and improve the teaching effectiveness.

\section{Experimental and practical teaching}

After years of construction, the Automobile Engineering Training Center of Linyi University has developed into a comprehensive experimental training center with complete laboratory equipment, perfect experiment measures, high level experimenters. The practical center includes automobile structure, automobile simulation driving, automobile electronics and appliances, engines, automobile disassembly, and other professional laboratories. Based on the experimental teaching system, the instruments and equipment are optimized to form a reasonable allocation, experimental teaching platform which can meet the modern experimental teaching requirements [11].

The schools of automobile and a number of automobile manufacturing, maintenance, sales companies have signed research cooperation agreement to establish long-term and stable off-campus practice bases. At the same time, the teaching team hires the enterprise's backbone experts as the technology practice instructor of students to exercise and improve the students' practical ability [12]. 


\section{Teaching resource construction}

When teaching the undertaken courses, the team teaches in the multimedia classroom by using multimedia courseware to assist teaching. The teachers use video presentations, animations and other modern teaching methods to achieve the modernization and diversification of teaching methods, guiding students to study actively and creatively.

The teachers have produced electronic teaching plans and multimedia courseware for each professional course. At the same time, the teaching resources of relevant courses, including curriculum syllabus, problem sets, mock examination papers are constructed.

\section{E. Network Teaching}

The teaching team fully uses the network teaching platform of Linyi University. Each teacher has established online courses; the students can make use of network resources to self-study and practice. Through the way of combining classroom teaching and online teaching, the teaching methods are more rich and vivid which can greatly enhance students' learning enthusiasm.

At the same time, teachers can take advantage of the exchange platform of course websites, timely release courserelated information to enable students to learn about the latest teaching dynamic. It can effectively mobilize the enthusiasm of students, increase learning interest and enhance the students' independent thinking and self-learning ability.

\section{CONCLUSIONS}

The teaching team of automobile detection and maintenance of Linyi University has achieved significant results in terms of teaching reform. The specialty of vehicle engineering was elected as one of the key specialties of Applied Talent Training Specialist University Project of Shandong province; The Automotive Engineering Training Center was funded by the Central Government Supporting Local College Developing Project; The specialty of automobile service engineering was awarded school-level characteristic specialty; The innovation experimental area of training pattern for entrepreneurial personnel training mode in automobile service field was made as school-level experimental area. The teaching team has obtained 4 teaching awards, more than 10 teaching reform projects, 3 excellent courses. It has published 3 textbooks, and published more than 20 teaching reform papers.

In years of teaching activities, the teams fully explored potential scientific potential, tracked the latest developments in automobile technology. It focuses on the training of students' operation ability and innovation spirit. The teachers encourage students to actively participate in various science and technology activities and competition.

All the teachers of teaching team actively carry out teaching reform, and the team spirit of unity and harmony is formed. Through course construction, training center automotive construction, scientific research, the teaching team's overall strength is gradually improved, the teaching quality has been highly praised by students, and the training of application ability of students gets confirmation from employing units and society.

The teaching team of automobile detection and maintenance should be built according to the discipline and specialty construction of vehicle engineering and automobile service engineering. By further promoting the teaching reform and curriculum construction, improving scientific research and social services, enhancing the cohesion of teachers, the teaching team with certain characteristics and influence can be constructed.

\section{ACKNOWLEDGMENT}

This work was supported by the Adult Higher Education Teaching Reform and Development Policy Research Project of Shandong, China, the Teaching Reform Project of Linyi University (No. 2014016), and the Teaching Quality Engineering Project of Linyi University in 2014.

\section{REFERENCES}

[1] X. Huang, "On Teaching Team Construction in University, Journal of West Anhui University", vol. 24, no. 1, pp. 39-41, February 2008

2] F. Liu, X. Chen, L. Wang, X. Mu, and G. Li, "Theory and Practice of Teaching Team Construction in University”, vol. 33, no. 1, pp. 5-8, February 2011.

[3] L. Du, C. Li, J. Lu, and Z. Wang, "Investigation on Strengthening the Construction of the Teaching team of Universities", vol. 9, no. 2, 86-90, June 2010.

[4] W. Wang, X. Meng, and Y. An, "Constructing Experimental Teaching Team with '211 Plan' Promotion program of university innovation ability", Experimental Technology and Management, vol. 30, no. 5, pp. 175-177, May 2013

[5] L. Liao, and G. Guo, "Study on the Construction of Automobile Service Engineering Major", Journal of Changzhou Institute of Technology (Social Science Edition), vol. 24, no. 2, pp. 107-109. April 2006.

[6] D. Cao, "Reform and Practice of Automotive Technology Curriculum", Journal of Wuhan Polytechnic, no. 2, pp. 39-43, April 2015.

[7] L. Yang, F. Tang, P. Kan, and X. Shu, "Construction Model Conception about Intramural Practice Training of Automobile Profession Based on Practice of College and Enterprise Cooperation", Journal of Hefe University (Natural Science), vol. 23, no. 1, 85-90, February 2013.

[8] X. Guan, H. Xue, and Y. Liu, "Approach to Construct Practical Training Base Automobile Specialized Subject of Higher Vocational Education", Journal of Liaoning Technical University (Social Science Edition), vol. 5, no. S, pp. 135-136, June 2003

[9] P. Chen, "Research and Practice of Bilingual Teaching for Electrical and Electronic Technology", Advanced Technology in Teaching, vol. 163, pp. 685-691, April 2012.

[10] X. Jiang, and P. Chen, "Study on Personnel Training Modes for Engineering Majors Based on Credit System", Education Managemen and Management Science, pp. 359 -362, July 2015.

[11] P. Chen, "Implementation Strategy Research on Team Graduation Design of Automobile Specialties Based on Engineering Project, Advances in Intelligent Systems Research", vol. 125, pp. 1516-1520, June 2015.

[12] M. Zhang, "Research on Resource Integration and Utilization Strategies of School-Enterprise in Linyi", Advances in Social Science Education and Humanities Research, vol. 17, 260-264, January 2015. 